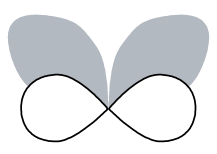

\title{
Mid-Holocene and glacial-maximum vegetation geography of the northern continents and Africa
}

\author{
I. Colin Prentice ${ }^{1}$, Dominique Jolly ${ }^{1,2,3}$ and BIOME 6000 participants* ${ }^{1}$ Max Planck \\ Institute for Biogeochemistry, Postfach 100164, D-07701 Jena, Germany, ${ }^{2}$ Dynamic \\ Palaeoclimatology, Lund University, Box 117, S-221 00 Lund, Sweden and ${ }^{3}$ School of \\ Ecology, Lund University, Ecology Building, S-223 62 Lund, Sweden
}

\begin{abstract}
BIOME 6000 is an international project to map vegetation globally at mid-Holocene $\left(6000{ }^{14} \mathrm{C} \mathrm{yr} \mathrm{BP}\right)$ and last glacial maximum (LGM, $\left.18,000{ }^{14} \mathrm{C} \mathrm{yr} \mathrm{BP}\right)$, with a view to evaluating coupled climate-biosphere model results. Primary palaeoecological data are assigned to biomes using an explicit algorithm based on plant functional types. This paper introduces the second Special Feature on BIOME 6000. Site-based global biome maps are shown with data from North America, Eurasia (except South and Southeast Asia) and Africa at both time periods. A map based on surface samples shows the method's skill in reconstructing present-day biomes.

Cold and dry conditions at LGM favoured extensive tundra and steppe. These biomes intergraded in northern Eurasia. Northern hemisphere forest biomes were displaced southward. Boreal evergreen forests (taiga) and temperate deciduous forests were fragmented, while European and East Asian steppes were greatly extended. Tropical moist forests (i.e. tropical rain forest and tropical seasonal forest) in Africa were reduced. In south-western North America, desert and steppe were replaced by open conifer woodland, opposite to the general arid trend but consistent with modelled southward displacement of the jet stream.

The Arctic forest limit was shifted slighly north at $6000{ }^{14} \mathrm{C}$ уг вр in some sectors, but not in all. Northern temperate forest zones were generally shifted greater distances north. Warmer winters as well as summers in several regions are required to explain these shifts. Temperate deciduous forests in Europe were greatly extended, into the Mediterranean region as well as to the north. Steppe encroached on forest biomes in interior North America, but not in central Asia. Enhanced monsoons extended forest biomes in China inland and Sahelian vegetation into the Sahara while the African tropical rain forest was also reduced, consistent with a modelled northward shift of the ITCZ and a more seasonal climate in the equatorial zone.

Palaeobiome maps show the outcome of separate, independent migrations of plant taxa in response to climate change. The average composition of biomes at LGM was often markedly different from today. Refugia for the temperate deciduous and tropical rain forest biomes may have existed offshore at LGM, but their characteristic taxa also persisted as components of other biomes. Examples include temperate deciduous trees that survived in cool mixed forest in eastern Europe, and tropical evergreen trees that survived in tropical seasonal forest in Africa. The sequence of biome shifts during a glacial-interglacial cycle may help account for some disjunct distributions of plant taxa. For example, the now-arid Saharan mountains may have linked Mediterranean and African tropical montane floras during enhanced monsoon regimes.
\end{abstract}

\footnotetext{
Correspondence: Professor I. C. Prentice, Max Planck Institute for Biogeochemistry, Postfach 100164, D-07701 Jena, Germany. E-mail: colin.prentice@bgc-jena.mpg.de "Members of the BIOME 6000 Project who contributed data or analysis for this paper: Afanas'eva, N. B., Ager, T. A., Anderson, K., Anderson, P. M., Andrieu, V., Andreev, A. A., Ballouche, A., Bartlein, P. J., de Beaulieu, J. L., Bengo, M., Berezina, N. A., Bezusko, L. G., Bezusko, T. V., Bigelow, N. H., Blyakharchuk, T. A., Bolikhovskaya, N. S., Bonnefille, R., Bottema, S., Brénac, P., Brubaker, L. B., Buchet, G., Burney, D., Bykova, G. V., Cheddadi, R., Chen, X., Chernavskaya, M. M., Chernova, G. M., Cwynar, L. C., Dorofeyuk, N. I., Dirksen, V. G., Edorh, T., Edwards, M. E., Eisner, W. R., Elenga, H., Elina, G. A., Elmoutaki, S., Filimonova, L. V., Glebov, F. Z., Guiot, J., Gunova, V. S., Hamilton, A. C., Han, H., Harrison, S. P., Hu, F.-S., Huang, C., Huntley, B., Jolly, D., Jonson, H., Ke, M., Khomutova, V. I., Kong Z., Kvavadze, E. V., Laarif, F., Lamb, H. E., Lézine, A.-M., Li, S., Li, W., Liew, P., Liu, G., Liu, J., Liu, Q., Liu, K.-B., Lozhkin, A. V., Maley, J., Marchant, R., Mbenza, M., MacDonald, G. M., Miyoshi, N., Mock, C. J., Morita, Y., Newby, P., Ni, J., Osipova, I. R., Panova, N. K., Perez-Obiol, R., Peyron, O., Prentice, I. C., Qiu, W., Reille, M., Ren, G., Reynaud-Farrera, I., Richard, P. J. H., Riollet, G., Ritchie, J. C., Roche, E., Saarse, L., Scott, L., Sevastyanov, D. V., Sher, A. V., Song, C., Spear, R. W., Ssemmanda, I., Straka, H., Sugita, S., Sun, X., Takahara, H., Tang, L., Tarasov, P. E., Taylor, D., Thompson, R. S., Uchiyama, T., Van Campo, E., Vilimumbalo, S., Vincens, A., Volkova, V. S., Waller, M., Webb, T., III, Williams, J. W., Xia, Y., Xu, Q., Yan, S., Yang, X., Yu, G., Zernitskaya, V. P., Zhao, J., Zheng, Z.
} 
Major changes in physical land-surface conditions, shown by the palaeobiome data, have implications for the global climate. The data can be used directly to evaluate the output of coupled atmosphere-biosphere models. The data could also be objectively generalized to yield realistic gridded land-surface maps, for use in sensitivity experiments with atmospheric models. Recent analyses of vegetation-climate feedbacks have focused on the hypothesized positive feedback effects of climate-induced vegetation changes in the Sahara/Sahel region and the Arctic during the mid-Holocene. However, a far wider spectrum of interactions potentially exists and could be investigated, using these data, both for $6000{ }^{14} \mathrm{C}$ yr BP and for the LGM.

\section{Keywords}

Pollen data, plant functional data, plant functional types, biomes, vegetation distribution, vegetation changes, biogeography, climate change, land-surface characteristics, mid-Holocene, last glacial maximum.

\section{INTRODUCTION}

BIOME 6000 (Prentice \& Webb, 1998) is a data synthesis project sponsored by the International Geosphere-Biosphere Programme (IGBP). The project came into being to support the ' $6000 \mathrm{yr}$ вр experiment', an initiative of the IGBP Task Force on Global Analysis, Interpretation and Modelling (GAIM). The 6000 yr BP experiment aims to use palaeodata from the mid-Holocene as a benchmark to evaluate simulations with coupled climate-biosphere models and thus to assess the extent of biogeophysical (vegetation-atmosphere) feedbacks in the global climate system (Anonymous, 1994). The success of this initiative depends on global vegetation data for the mid-Holocene being available, in a form allowing direct comparison with model output. The primary aim of BIOME 6000 is, accordingly, to map global biome distributions at the mid-Holocene $\left(6000 \pm 500{ }^{14} \mathrm{C}\right.$ yr BP $)$.

GAIM also envisages model experiments focused on the last glacial maximum (LGM), especially with regard to understanding the natural changes in atmospheric composition between glacial and interglacial periods (Anonymous, 1994). A secondary aim of the BIOME 6000 project is therefore to create a similar map for the LGM $\left(18,000 \pm 2000{ }^{14} \mathrm{C}\right.$ yr вP). The mid-Holocene and LGM are the two key time periods adopted by the Palaeoclimate Modelling Intercomparison Project, PMIP (Joussaume \& Taylor, 1995). PMIP and GAIM modelling studies are based on the premise that the midHolocene (taken for modelling purposes as $6000 \mathrm{cal} \mathrm{yr} \mathrm{вр)}$ represents an 'orbital forcing experiment', with perihelion in northern summer/autumn and greater-than-present axial tilt, but free of major ice-sheet and $\mathrm{CO}_{2}$ effects. The LGM (taken for modelling purposes as $21,000 \mathrm{cal} \mathrm{yr} \mathrm{BP}$ ) represents by contrast primarily an experiment on the effects of enlarged ice sheets and low atmospheric $\mathrm{CO}_{2}$.

BIOME 6000 has provided a unique opportunity for palaeoecologists to work together towards a globally comprehensive documentation of the response of the terrestrial biosphere to specific climate changes in the past. The project is community-wide and engages palaeoecologists from all continents. BIOME 6000 is distinguished from previous palaeoecological data compilations by its global scope, combined with its use of a standardized, objective method (biomization) based on plant functional types (PFTs: Steffen et al., 1992; Prentice et al., 1996) to assign palaeoecological data (pollen or plant macrofossil records) to biomes. Results are presented in the form of maps in which every site is shown and can be traced to an original pollen or macrofossil count, or (if unavoidable) a record digitized from a pollen diagram. This approach eliminates the subjectivity inherent in more traditional palaeogeographic map reconstructions. The idea is to compile data of high quality whose origin and validity can always be checked, and which can be built on further as new data become available.

This paper introduces the second Journal of Biogeography Special Feature devoted to BIOME 6000. Papers presented in the first Special Feature (Prentice \& Webb, 1998) established the practicality and robustness of the biomization technique, first developed and tested for Europe (Prentice et al., 1996), when applied to pollen and plant macrofossil data from poor (e.g. Siberia) to rich (e.g. tropical Africa) floras and including Arctic, oceanic and continental midlatitude, arid to moist subtropical, and wet- and dry-tropical climates (Jolly et al., 1998a; Tarasov et al., 1998; Yu et al., 1998). In each of these regional studies, the method was first applied to modern (surface pollen sample) data and shown to successfully reconstruct the modern biome distribution. Then the method was applied without change to $6000{ }^{14} \mathrm{C}$ yr вp data and found to generate spatially coherent and plausible reconstructions of biome distribution for that time. The study for China (Yu et al., 1998) was a pilot study based on a subset of the available pollen records and taxa, relying mainly on digitized pollen records. The other studies, for Africa (Jolly et al., 1998a) and the former Soviet Union eastward to $\approx 130^{\circ} \mathrm{E}$ (Tarasov et al., 1998), were comprehensive and based largely or entirely on complete taxon lists.

Papers in this second Special Feature extend the geographical coverage of the $6000{ }^{14} \mathrm{C} \mathrm{yr}$ BP reconstructions, and equip all of the regions studied at $6000{ }^{14} \mathrm{C} \mathrm{yr}$ вP with 
biome reconstructions for the LGM. The papers featured here deal with southern Europe and Africa at LGM (Elenga et al., 2000), a new and comprehensive analysis for China at $6000{ }^{14} \mathrm{C}$ yr BP and LGM (Yu et al., 2000), $6000{ }^{14} \mathrm{C}$ yr вP and LGM reconstructions for Japan (Takahara et al., 2000), an extension of the Tarasov et al. (1998) $6000{ }^{14} \mathrm{C}$ yr в study to cover northern Eurasia at LGM (Tarasov et al., 2000), and $6000{ }^{14} \mathrm{C}$ yr BP and LGM reconstructions for three $\mathrm{New}$ World' biogeographic regions: Beringia (Russian Federation east of $130^{\circ} \mathrm{E}$, plus Alaska and the Mackenzie Delta region; Edwards et al., 2000), the western USA (Thompson \& Anderson, 2000), and eastern North America and Canada (Williams et al., 2000). This scheme for dividing up the continents is based partly on practical considerations (e.g. existing co-operative projects) and partly on biogeographical considerations-for example, the overlap of flora between Alaska and eastern Siberia, and the distinctness of the flora of the western USA from that of the rest of North America.

These papers, together with those published in the first Special Feature, provide $6000{ }^{14} \mathrm{C}$ yr BP and LGM coverage for Africa, Eurasia (apart from South-east Asia and the Indian subcontinent), and North America southward to the US-Mexican border. They document an evolution of the methodology, with an increasing focus on obtaining primary data and using the information in minor taxa that may have important indicator value for biomes (especially when distinguishing nonforest biomes where pollen records are typically dominated by a few pollen taxa of broad ecological tolerance, such as Artemisia and Poaceae), and progress by iteration towards a global set of PFTs that will ultimately be useful for biome modelling as well as for reconstructing past biomes. Another important development is the use of plant macrofossil records as a major information source. Charcoal records were already included in the earlier African study by Jolly et al. (1998a) and tree megafossils were included to document Arctic treeline regression since $6000{ }^{14} \mathrm{C}$ yr вP by Texier et al. (1997). A more extensive use of plant macrofossils is provided here by Thompson $\&$ Anderson (2000), who use packrat midden assemblages as a major data source in addition to pollen data to reconstruct vegetation changes in the arid south-western USA.

This introductory paper represents a preliminary synthesis, based on the combined results of the BIOME 6000 project to date. We consider the potential significance of these results from several standpoints: as a simple record of biogeographic shifts; as documentation of vegetation's long-term response to climate change; as a historical background to understanding the shifting geographical ranges of plant taxa in the face of a changing climate; and as data for the evaluation and improvement of approaches to modelling climate change, as envisaged in the GAIM 6000 yr вP experiment.

\section{RECONSTRUCTION OF PRESENT-DAY VEGETATION PATTERNS}

Surface samples provide a way to test the validity of the method used to reconstruct past biomes. Figure 1 combines results obtained with surface pollen samples for each of the regions. The individual papers should be consulted for detailed comparisons between these patterns and modern vegetation distribution in each region. Taken together, these modern vegetation reconstructions convincingly recreate the broad features seen in any modern vegetation map. Surface data are, however, sparse or absent in a few regions: part of eastern Siberia and the Russian Far East; the African deserts, and the miombo (a type of tropical dry forest) and equatorial rain forest regions of Africa.

Occasional samples from tundra regions, especially from islands in the high Arctic (e.g. Banks Island, Svalbard, Björnöya), are misclassified as taiga or cold deciduous forest due to the weak local pollen signal being overwhelmed by transport of tree pollen types from distant forest regions (Prentice, 1988). In the areas of most intense cultivation (eastern China, western Europe, eastern USA), a proportion of samples from forest biomes are misclassified into nonforest biomes (mainly desert and steppe). Nevertheless, most samples even in these regions are assigned to the correct (forest) biome, confirming the method's robustness against all but the most intensive human impact (Prentice et al., 1996).

\section{THE PALAEOVEGETATION MAPS AND THEIR PALAEOCLIMATIC SIGNIFICANCE}

\section{Last glacial maximum}

The map for LGM (Fig. 2) illustrates a 'glacial world' that differs radically from that of today. The most obvious features are the equatorward regression of forest types in North America and Eurasia (in the unglaciated eastern part of Eurasia, as well as in Europe) and compression and fragmentation of the forest zones in these regions. The boreal evergreen forest (taiga) occupied a far smaller area than today and temperate deciduous forest was very restricted. Existing forest types were ousted from southern China and the south-eastern USA: there are only a few LGM records of broadleaved evergreen/warm mixed forests in the southeastern USA, and no LGM records of tropical forests in southern China. Only a few regions show the same biome at LGM as today. One such region is central Asia; even there, however, Tarasov et al. (2000) point out that the persistence of the steppe biome hides changes in the floristic composition of the steppe. In the most general climatic terms, these shifts document the response of the terrestrial biosphere to a large year-round reduction in temperature, relative to the present.

The biome shifts also provide evidence for drier conditions than present across large areas of the mid-latitudes. In central Asia and Siberia tundra encroached much further south than today (Edwards et al., 2000), but further large areas of what is now forest were occupied by a kind of steppe (Tarasov et al., 2000). As suggested by palaeoclimate-biome model experiments (e.g. Prentice et al., 1993), it appears that tundra and steppe at LGM had a long common frontier or intergradation zone in Eurasia. This is in contrast with today, where tundra-steppe intergradation only occurs in a few very dry regions, such as along elevation gradients in central Asia and Alaska. We have avoided using the term 'steppe-tundra', 

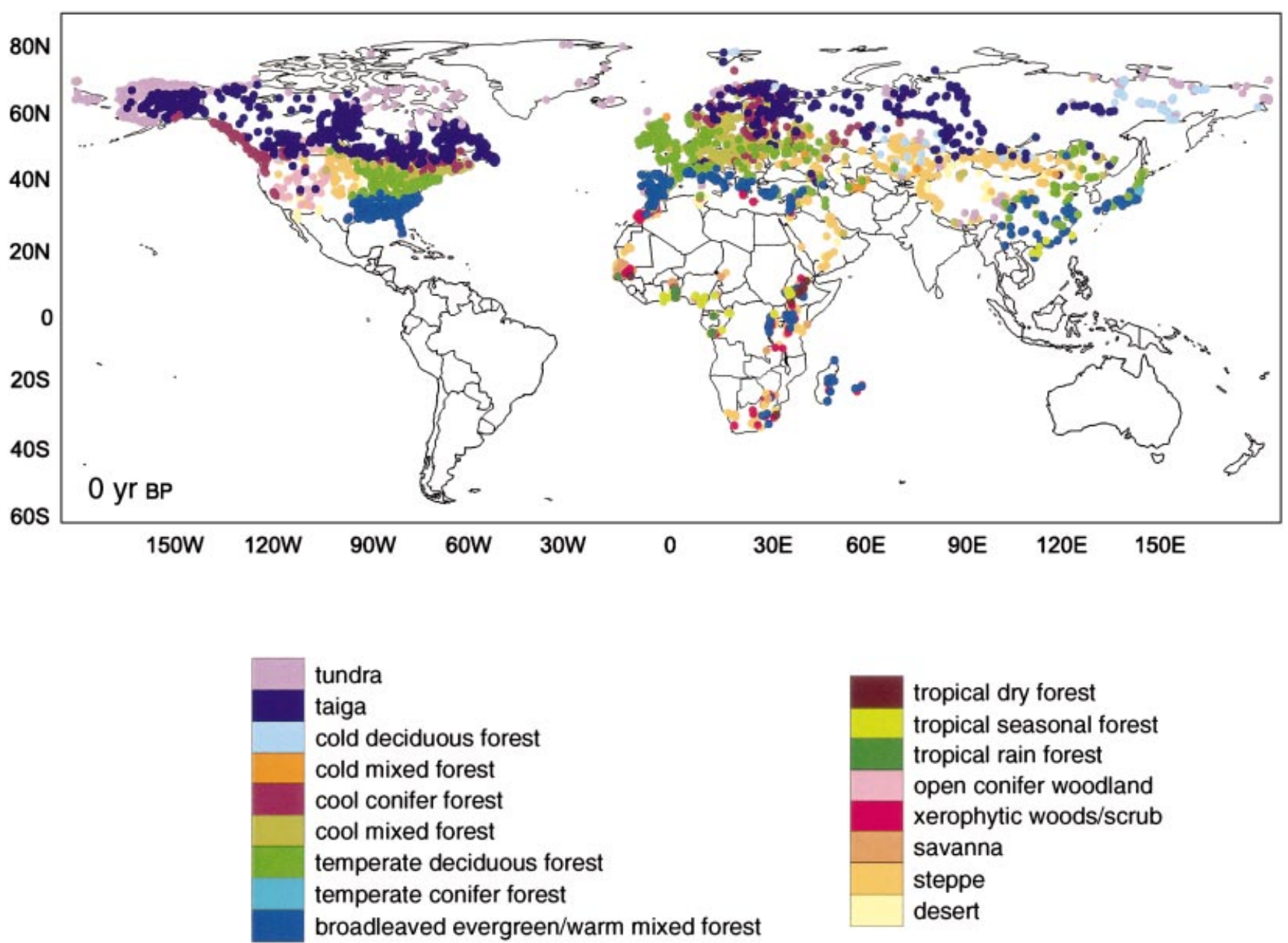

tundra
taiga
cold deciduous forest
cold mixed forest
cool conifer forest
cool mixed forest
temperate deciduous forest
temperate conifer forest
broadleaved evergreen/warm mixed forest

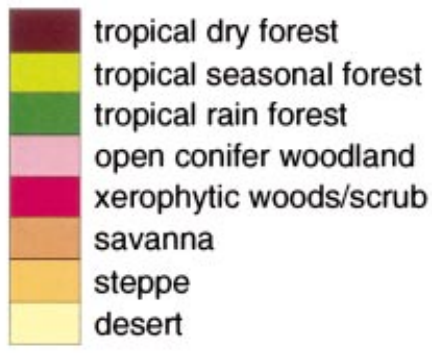

Figure I Present-day biomes reconstructed from surface pollen samples. The biomes are plotted in a globally consistent order. In regions characterized by complex vegetation patterns, overprinting of some sites at the small scale of these maps may result in small apparent differences with the larger-scale regional maps.

but this concept is given some support by the existence of an intergradation between these two biomes at LGM. Tarasov et al. (2000) show that the position of the reconstructed boundary between steppe and tundra is somewhat sensitive to the classification of certain shrub and forb taxa that are treated differently in the Beringia study (Edwards et al., 2000); further work is required to establish a universal circumpolar classification scheme. Nevertheless, the LGM vegetation in Beringia was unambiguously tundra (Elias et al., 1997; Edwards et al., 2000) while the LGM vegetation in central Asia and southern and south-eastern Europe (Tarasov et al., 2000; Elenga et al., 2000) was clearly steppe. Affinity scores for the two biomes, as used in the biome assignment algorithm, confirm that there was a gradient from tundra to steppe. For example, in Europe the more northerly LGM samples (from France) assigned to steppe also have relatively high scores for tundra (Elenga et al., 2000). In Alaska, where the LGM samples are consistently assigned to tundra, these samples nevertheless have higher scores for steppe than do tundra samples from Alaska today or in the Holocene (Edwards et al., 2000).

Temperate deciduous forests in Europe, North America and Asia were 'squeezed' not only by the southward encroachment of more cold-tolerant or cold-requiring forest types, but also by the extension of nonforest vegetation (Elenga et al., 2000; Tarasov et al., 2000; Yu et al., 2000; Williams et al., 2000). This phenomenon is most marked in China, where steppe and even desert extended eastward to the modern coastline in what is now the temperate deciduous forest belt, suggesting a strongly reduced East Asian summer monsoon at LGM (Yu et al., 2000).

The equatorial region and the southern hemisphere are represented here only by Africa. Although the available LGM data from tropical Africa are sparse, they too document not only cooling (as shown by the downward elevational shift of broadleaved evergreen/warm mixed forest) but also drying (as shown by the encroachment of steppe into regions now occupied by tropical forests) (Elenga et al., 2000). In southern 


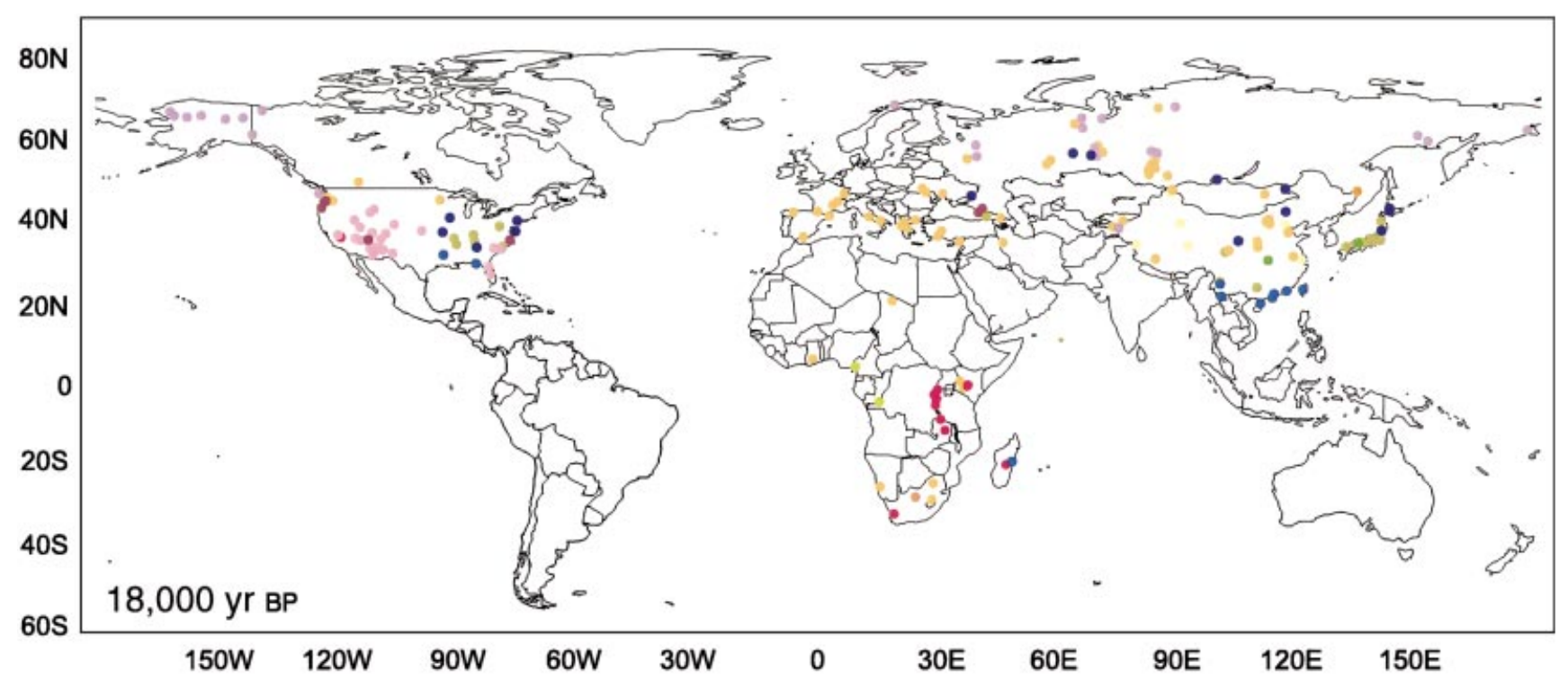

\begin{tabular}{l}
\hline tundra \\
taiga \\
cold deciduous forest \\
cold mixed forest \\
cool conifer forest \\
cool mixed forest \\
temperate deciduous forest \\
temperate conifer forest \\
broadleaved evergreen/warm mixed forest
\end{tabular}

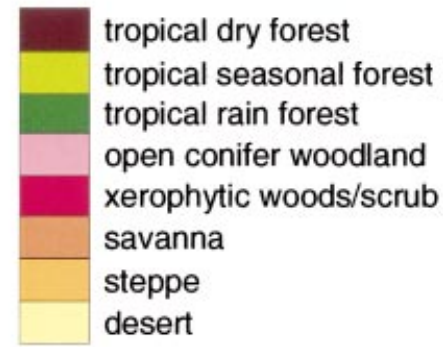

Figure 2 Reconstructed biomes at LGM. The biomes are plotted in a globally consistent order. In regions characterized by complex vegetation patterns, overprinting of some sites at the small scale of these maps may result in small apparent differences with the larger-scale regional maps.

Africa, the data similarly show xerophytic woods/scrub being replaced by steppe at the LGM.

The one striking exception to this pattern of drying is provided by the south-western USA, where a modelled southward displacement of the jet stream in response to the presence of the Laurentide ice sheet can explain high lake levels and the observed presence of open conifer woodlands in regions that are steppe or desert today (e.g. COHMAP Members, 1988; Thompson et al., 1993). A similar though less pronounced jet-stream displacement may have occurred in Europe (Kutzbach \& Guetter, 1986; Harrison et al., 1992). However, while lake levels in southern Europe were high, the vegetation was uniformly steppe-suggesting that summer precipitation, at least, was insufficient to sustain forest (Prentice et al., 1992).

Low atmospheric $\mathrm{CO}_{2}$ concentration at LGM may have contributed to low plant-available moisture (PAM) by reducing plant water-use efficiency (Farrera et al., 1999) and may have played a role in the lowering of tropical treelines during the glacial period (Jolly \& Haxeltine, 1997; Street-Perrott et al.,
1997). This effect does not, however, eliminate reductions in continental precipitation as a major cause of biome shifts. Indeed such reductions are a common feature of model simulations of the LGM climate for the low and mid-latitudes (Pinot et al., 1999), except in those regions (most importantly the south-western USA) where the data show increased PAM and models show increased precipitation. Thus, the broad-scale biome shifts shown by the data can plausibly be taken to reflect a climate with temperatures and precipitation lower than present over most of the northern hemisphere.

\section{Mid-Holocene}

In the northern circumpolar region, the mid-Holocene data show forests (taiga, cold deciduous forest) extended polewards at the expense of tundra, indicating greater-than-present growingseason warmth, in the Mackenzie Delta region (Canada) (Ritchie, 1985, 1987; MacDonald, 1995), the European Arctic (Hyvärinen, 1976) and western and central Siberia (Texier 


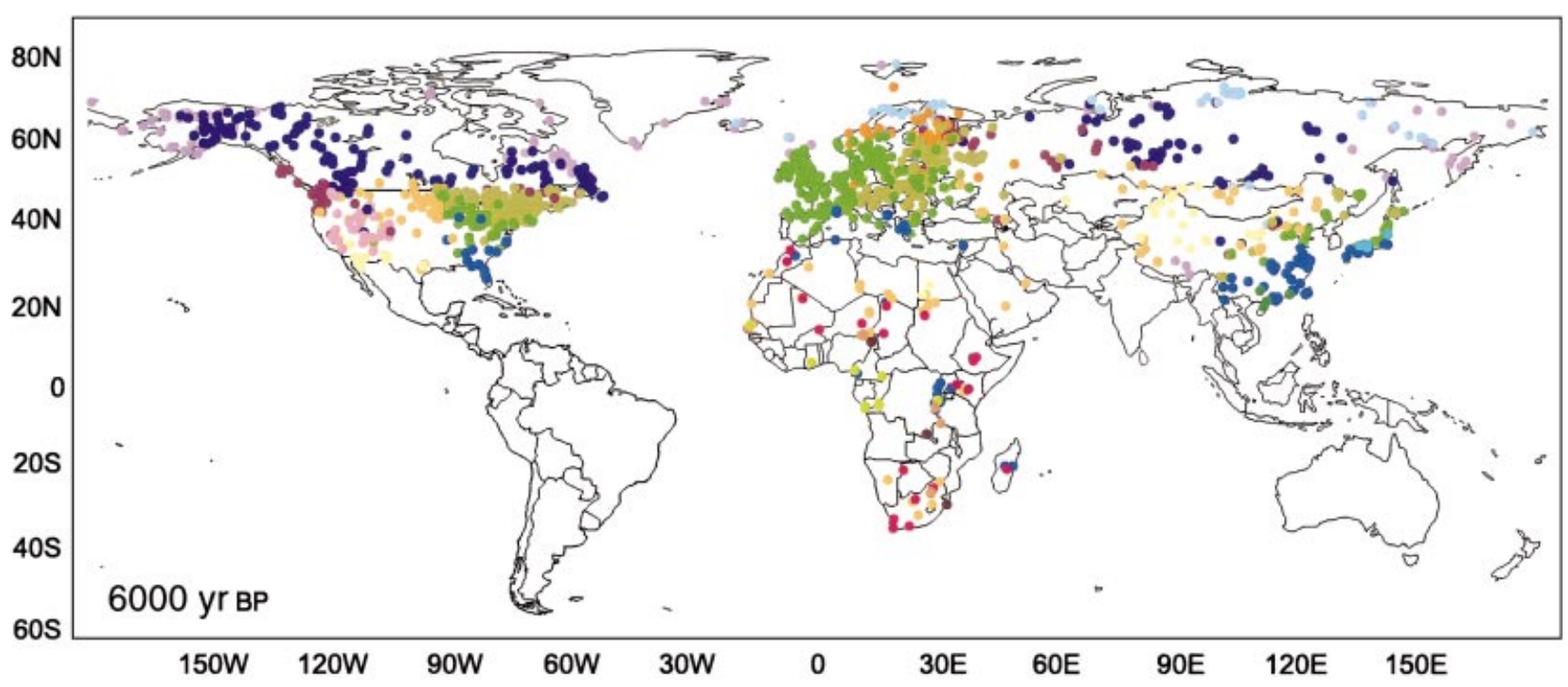

\begin{tabular}{|l}
\hline tundra \\
taiga \\
cold deciduous forest \\
cold mixed forest \\
cool conifer forest \\
cool mixed forest \\
temperate deciduous forest \\
temperate conifer forest \\
broadleaved/warm mixed forest \\
\hline
\end{tabular}

tropical dry forest tropical seasonal forest tropical rain forest open conifer woodland xerophytic woods/scrub savanna steppe desert

Figure 3 Reconstructed biomes at 6000 yr вр. The biomes are plotted in a globally consistent order. In regions characterized by complex vegetation patterns, overprinting of some sites at the small scale of these maps may result in small apparent differences with the larger-scale regional maps.

et al., 1997; Tarasov et al., 1998) (Fig. 3). However, this shift was at most $200-300 \mathrm{~km}$. In the Mackenzie Delta region, the shift has been estimated as only about $25 \mathrm{~km}$ (MacDonald, 1995). The shift appears relatively slight when viewed on global maps. Furthermore it is not symmetrical around the pole. There was no discernible northward treeline shift in Alaska despite the relatively high density of sites that would allow such a shift to be detected, if it had occurred (Edwards et al., 2000). There is no clear evidence for a northward shift in Keewatin, although the data from that region are too sparse to allow certainty on this point (MacDonald, 1995; Williams et al., 2000). In Québec-Labrador, treeline was slightly south of its present position (Richard, 1995; Williams et al., 2000). In eastern Siberia, where the Arctic treeline is formed by cold decidous forest, low pollen production by the dominant tree taxon (Larix) makes the pollen-based definition of treeline uncertain (Edwards et al., 2000). Nevertheless the forest and tundra can be distinguished at a broad-scale even in this region, and there is no clear evidence for the forest being further north than present at $6000{ }^{14} \mathrm{C}$ yr вP.
Explanations of the $6000{ }^{14} \mathrm{C}$ yr вр climate will thus have to account for a strong asymmetry of the circumpolar warming, perhaps reflecting a changed ocean circulation in the Arctic Basin. Accurate representation of the forest-tundra boundary is itself important for climate modelling because even a slight shift can have substantial consequences for the northern-hemisphere energy balance (Foley et al., 1994; TEMPO, 1996). The shifts of the Arctic treeline between $6000{ }^{14} \mathrm{C} \mathrm{yr} \mathrm{BP,} \mathrm{although} \mathrm{slight} \mathrm{in} \mathrm{terms} \mathrm{of} \mathrm{distance,} \mathrm{may}$ therefore have been significant in terms of climate feedbacks. Our ability to model these effects today is limited.

The general pattern across the northern mid-latitudes of Eurasia is one of poleward shifts of the forest belts. Although the distances involved are small compared to the changes between LGM and present, many of the shifts are far more dramatic than the change in the position of the Arctic treeline between $6000{ }^{14} \mathrm{C}$ yr BP and present. In many cases these shifts implicate warmer winter conditions at $6000{ }^{14} \mathrm{C}$ yr вр even though the orbital forcing alone would tend in the direction of colder winters (Kutzbach \& Guetter, 1986). For 
example, the northward and eastward extension of temperate deciduous forest in Europe requires that winters were too warm to satisfy the winter-chill requirements of boreal conifers (Huntley \& Prentice, 1993). Similarly, the slight northward and upward extension of the broadleaved evergreen/ warm mixed forest limit in China implies that broadleaved evergreen trees at this latitude were subject to less frequent killing frosts than they would be at the same latitude today (Yu et al., 1998, 2000).

The paradox of warm mid-Holocene winters has been extensively discussed for Europe (Harrison et al., 1992; Huntley \& Prentice, 1993; Cheddadi et al., 1997; Masson et al., 1998; Prentice et al., 1998) and various mechanisms have been proposed to account for it. Climate models however, have failed to produce any (or a strong enough) winter warming in Europe (Harrison et al., 1998). For China, Sun \& Chen (1996) and Yu et al. (1998, 2000) have proposed that the changes reflect a reduced strength of the East Asian winter monsoon. In Japan the situation is more complicated because where broadleaved evergreen/warm mixed forests grow today, the dominant vegetation at $6000{ }^{14} \mathrm{C}$ yr BP was temperate conifer forest. Takahara et al. (2000) interpret this difference as a consequence of summer warming creating a more seasonal climate, close to that of the small areas where temperate conifers such as Cryptomeria thrive now. In eastern North America, by contrast, the shifts of the forest belts are in a direction suggesting winters similar to or colder than present (Prentice et al., 1991; Webb et al., 1993; Williams et al., 2000). Thus, there is apparently a circumpolar asymmetry also in the response of the wintertime atmospheric circulation to orbital forcing at $6000{ }^{14} \mathrm{C}$ yr BP, manifested in qualitatively different biome shifts on the different continents.

In the mid-continents, there is some evidence of drying associated with the expanded distribution of steppe at the expense of forest in the Great Lakes region and the western interior of Canada (Prentice et al., 1991; Webb et al., 1993; Williams et al., 2000). Once again, however, the hemispheric pattern is asymmetrical: south-eastern Europe and central Asia show the opposite trend, with forest biomes encroaching on the present-day steppe (Tarasov et al., 1998). Thus, it may be that the shift of the steppe-forest boundary in North America is not a simple consequence of warm summers leading to higher evaporation rates and reduced soil moisture, as one might guess, but rather a reflection of a global atmospheric circulation shift. Alternatively, the direct evaporation effect may be overridden in Eurasia because of the importance of monsoonal circulations in bringing moisture into the midcontinent. This problem bears on the question of possible future trends in mid-continental aridity (Kattenberg et al., 1996) and requires further analysis to isolate the various possible mechanisms involved.

The circum-Mediterranean region shows temperate deciduous forest encroaching southward and xerophytic woods/ scrub reduced in extent at $6000{ }^{14} \mathrm{C} \mathrm{yr} \mathrm{BP}$, suggesting a moister climate than today (Huntley \& Prentice, 1993). Progressive aridification of this region since $6000{ }^{14} \mathrm{C} \mathrm{yr} \mathrm{в}$ is also shown by some lake-level records (Harrison \&
Digerfeldt, 1993; Yu \& Harrison, 1996), isotopic records (Araus et al., 1997) and the palaeosalinity record of the Mediterranean Sea itself (Kallel et al., 1997). However, the underlying climatic mechanisms are not understood. Climate model simulations generally have produced wetter winters but not summers in southern Europe at $6000 \mathrm{yr}$ BP (Harrison et al., 1998), whereas this vegetation shift requires increased $\mathrm{PAM}$ at $6000{ }^{14} \mathrm{C} \mathrm{yr} \mathrm{BP}$. Increased winter precipitation in most of the Mediterranean-climate area would accrue to runoff, but would not increase PAM (Prentice et al., 1993). This problem is also relevant to future trends because many climate model simulations with increased $\mathrm{CO}_{2}$ show increasing winter precipitation in the Mediterranean region accompanied by summer drought (Kattenberg et al., 1996), just as they show for the mid-Holocene (Hewitt \& Mitchell, 1996).

The largest changes of all at $6000{ }^{14} \mathrm{C}$ yr BP are seen in the monsoon regions, above all in northern Africa, where the Sahara desert was drastically reduced and the Sahelian vegetation belts (i.e. steppe, xerophytic woods/scrub, tropical dry forest) shifted systematically northwards (Jolly et al., 1998a). The basic mechanism of monsoon amplification due to early to mid-Holocene orbital forcing is well established (Kutzbach \& Street-Perrott, 1985; Kutzbach \& Guetter, 1986; COHMAP Members, 1988; de Noblet et al., 1997) but further positive feedback mechanisms, involving land-surface changes (Street-Perrott et al., 1990; Kutzbach et al., 1996; Broström et al., 1997; Claussen \& Gayler, 1997; Texier et al., 1997) and/or sea-surface changes (Kutzbach \& Liu, 1997; Hewitt \& Mitchell, 1998), need to be invoked in order to account for the magnitude of the biome shifts in Africa (Harrison et al., 1998; Braconnot et al., 1999; Joussaume et al., 1999).

Africa was not uniformly wetter than present at $6000{ }^{14} \mathrm{C}$ yr BP. The (admittedly limited) data from equatorial Africa show that the area of the tropical rain forest biome in Africa (excluding possible offshore locations at LGM) may be greater now than it was either at LGM or at $6000{ }^{14} \mathrm{C}$ yr BP (Jolly et al., 1998a, b). At $6000{ }^{14} \mathrm{C}$ yr BP, the contracted rain forest area suggests a more seasonal precipitation climate. Model simulations predict a more seasonal climate as a consequence of a more northerly location of the intertropical convergence zone (ITCZ) during northern hemisphere summer (Harrison et al., 1998; Joussaume et al., 1999). The reduction of tropical rain forest may therefore be dynamically linked to the expansion of moisture-demanding biomes further north (Prentice \& Sarnthein, 1993; Mommersteeg et al., 1995).

\section{IMPLICATIONS FOR PALAEOECOLOGY AND PHYTOGEOGRAPHY}

The palaeobiome maps presented here raise questions about the ecological mechanisms that have allowed plant taxa to persist in the face of climate changes on the time scale of glacial-interglacial cycles. One of the most important contributions of Quaternary palaeoecology to evolutionary biology has been the perspective that plant species must migrate if they are to survive climate change; this migration has the effect of mixing and homogenizing gene pools, and therefore opposes 
rather than promotes speciation (Bartlein \& Prentice, 1989; Huntley \& Webb, 1989; Bennett, 1997). Palaeoecologists have also demolished the notion that ecological communities can be considered as ancient, coevolved entities, since climate change evokes differential responses in the constituent taxa so that the taxonomic composition of biomes during one climatic phase can be very different from that during another phase (Colinvaux, 1987; Davis, 1990; Prentice, 1992). Several papers in this issue (Edwards et al., 2000; Williams et al., 2000; Elenga et al., 2000) demonstrate this point graphically with respect to the composition of biomes at LGM. Even in terms of the contributing plant functional types, it can be shown that biomes do not maintain a fixed composition through time; the same applies a fortiori to the species that make up the functional types.

The data presented here underline these dynamic perspectives on phytogeography. Biomes are mapped on the basis of the taxonomic composition of palaeoecological communities, but the biome assignment is an emergent property based on functional properties. Two assemblages, even in the same biogeographic province, need not have any taxa in common in order to be assigned to the same biome. This logical separation of biomes and taxa is important to consider when evaluating possible refugia for taxa during periods that are unfavourable to particular biomes. Two biomes that are seemingly absent (or nearly so) from the regions covered by Fig. 2 at LGM are temperate deciduous forest and tropical rainforest; this raises the question of where the constituent taxa were able to persist. Several possibilities exist and are not mutually exclusive.

1 These biomes existed somewhere on the present land surface, but palaeoecologists have not found sites in the right place. This possibility cannot be ruled out completely but it becomes less likely as more data are collected. The broad-scale distributions of taxa and biomes are constrained by climate, which imposes a degree of spatial coherence. Arbitrary distributions of taxa and biomes are not climatically possible, although distributions can be complex and many climatically differentiated taxa can coexist at a regional scale in regions of high relief.

2 Larger areas of these biomes existed offshore, on the areas of continental shelf that were exposed at LGM. This may be the case, for example, for temperate deciduous forest in China (Yu et al., 2000). Adequate precipitation for forest growth may have been available in the continental shelf region to the south and east, which could also have provided the source for re-population of Japan with deciduous trees after the LGM (Takahara et al., 2000). It also seems likely that tropical tree species, now found along the southern coast of China but completely ousted at LGM, could have survived further south on the exposed South China Sea shelf.

3 The taxa in question may have persisted as minor components in other biomes. This is certainly true for a number of temperate deciduous tree taxa that the pollen data show to have survived the LGM in broadleaved evergreen/ warm mixed forests in southern China (Yu et al., 2000), and others that survived the LGM in cool mixed forest in eastern Europe (Tarasov et al., 2000). Similarly, a number of tropical rain forest taxa persisted in tropical seasonal forest through the LGM and Holocene in equatorial Africa (Elenga et al., 2000).

Consideration of the time sequence from LGM through $6000{ }^{14} \mathrm{C}$ yr BP to present prompts further speculations about the distributional history of plant taxa. For example, a long-standing phytogeographic puzzle (Quézel \& Barbero, 1993) concerns species that are common to the floras of African tropical mountains and the Mediterranean region. The classic example is Erica arborea (Bruneau de Mire \& Quézel, 1959; Quézel, 1978). Similarities between these regions in terms of vegetation structure and function are easy to understand: African montane and Mediterranean environments today are characterized by the occurrence of the broadleaved evergreen/warm mixed forest and xerophytic woods/scrub biomes, in similar bioclimates. However, it is less obvious how the respective floras could have been connected in the past, since they are separated today by thousands of kilometres of desert. A key to this puzzle is provided by the palaeodata, indicating that earlier in the Holocene conditions in the Sahara region were far more moist than present and in particular that the Saharan mountains supported woodland or scrub, including typically Mediterranean taxa such as Quercus ilex and Pistacia spp. as well as Erica spp. (Wickens, 1984), as recently as $6000{ }^{14} \mathrm{C}$ yr BP (Jolly et al., 1998a). This climatic history may also explain the occurrence today of species apparently of Mediterranean origin, such as the endemic Cupressus dupreziana, in the Saharan mountains (Quézel \& Barbero, 1993).

In general, favourable conditions for the existence of broadleaved evergreen trees in the present Sahara desert could have existed for millenia during every climatic cycle during those periods where orbital forcing caused strong northern-hemisphere monsoons. This argument is reinforced when it is noted that $6000{ }^{14} \mathrm{C} \mathrm{yr}$ BP postdates the peak of wetness in northern Africa during the Holocene, with more developed vegetation occurring in the Sahara during earlier millennia (Jolly et al., 1998b); even wetter conditions prevailed during the last interglacial. We thus speculate that climatic oscillations on the Milankovitch time scale allowed repeated mixing of floras during some phases, while forcing disjunctions during others. In order to evaluate such speculations more critically it will be necessary to examine more complete time sequences of taxon and biome distributions. Prentice \& Webb (1998) stressed the importance of palaeoecological data bases, which ultimately will allow palaeobiome mapping to be essentially automated and therefore feasible for continuous time.

\section{IMPLICATIONS FOR PALAEOCLIMATE MODELLING}

The most straightforward use of the palaeobiome data in the context of climate modelling is to evaluate standard palaeoclimate simulations, such as those being generated by PMIP, and simulations in which biosphere and atmosphere are coupled in some way, as envisaged by the GAIM $6000 \mathrm{yr}$ 
BP experiment. Diagnostic procedures based on biome modelling have been developed to translate climate model output into predictions of biomes (Claussen \& Esch, 1994; Harrison et al., 1995; Ciret \& Henderson-Sellers, 1997, 1998; Harrison et al., 1998; Kutzbach et al., 1998), and such procedures form part of the 'equilibrium asynchronous coupling' approach to the inclusion of vegetation feedbacks in atmospheric models (e.g. Texier et al., 1997). Thus, model results obtained with or without explicit vegetation feedbacks can be compared with the palaeobiome data on a site by site basis. This site by site approach to data-model comparison is generally preferable to grid-based approaches, because numerous assumptions are hidden in all methods that could be used to interpolate palaeodata to a grid. Broccoli \& Marciniak (1996) have made this point with respect to CLIMAP sea-surface data, i.e. that some of the more controversial features of the much-cited gridded data set provided by CLIMAP rest on extrapolation from a limited number of (ín some cases questionable) data points. Thus, discrepancies between CLIMAP data and model results may have been overestimated. Similar and equally forceful arguments can be made for terrestrial palaeodata of all kinds, including palaeocological data assigned to biomes.

However, there are specific purposes that would call for the development of best-possible gridded data sets for terrestrial biomes. The conventional paradigm in climate modelling treated the land surface as unchanged from present. In reality, however, the physical properties of the land surface at 6000 ${ }^{14} \mathrm{C}$ yr вр (and even more so at LGM) were considerably altered. Biomes differ in properties such as surface albedo and roughness length that are important in controlling the fluxes of energy, water and momentum between the ground and the atmosphere, with consequences for the atmospheric heat balance and circulation; there is therefore a considerable potential for biogeophysical feedbacks (Eltahir, 1996; Melillo et al., 1996; Prentice, 1998). Much attention has been paid recently to two specific cases at $6000 \mathrm{yr}$ BP where this feedback appears to be positive: the effect of extended northern forests in generally enhancing northern-hemisphere warming (Foley et al., 1994; Melillo et al., 1996; TEMPO, 1996; Texier et al., 1997), and the effect of vegetation expansion in the Sahara in amplifying the enhancement of the African monsoon (Street-Perrott et al., 1990; Kutzbach et al., 1996; Broström et al., 1997; Claussen \& Gayler, 1997; Texier et al., 1997). These studies have adopted one of three approaches to quantifying biogeophysical feedback: (1) stylized vegetation changes have been prescribed as part of the boundary conditions of the climate model (e.g. Street-Perrott et al., 1990; Foley et al., 1994); (2) the climate model has been linked to a biome model using equilibrium asynchronous coupling (e.g. de Noblet et al., 1996; Claussen \& Gayler, 1997; Texier et al., 1997); (3) realistic vegetation changes have been prescribed, based on the available data with an explicit procedure used to generalize the data to the climate model grid (Broström et al., 1997; Hoelzmann et al., 1998). Various objective procedures exist that could accomplish such gridding of qualitative (biome) data in a topographically sensitive manner (e.g. Guiot et al., 1996).
Approaches (1) and (3) are sensitivity experiments, whereas approach (2) represents a prognostic approach that could also be applied to predicting future climate changes or to understanding climate changes during periods for which the available data on vegetation are limited (e.g. the start of the last glaciation: de Noblet et al., 1996). Coupled prognostic modelling remains the ultimate goal, particularly fully coupled modelling in which the atmosphere and biosphere interact on the time scale of the climate model itself (Foley et al., 1998). Sensitivity experiments however, are also valuable because they make it possible to isolate the effects of one particular type of feedback, e.g. land-surface changes. Imposing stylized changes results in ambiguity in interpreting the results and could even lead to artefacts if the vegetation changes prescribed were inconsistent with any plausible climate. For this reason, it is preferable to prescribe land-surface conditions as accurately as possible, i.e. approach (3) is preferred to (1). Broström et al. (1997) prescribed land-surface conditions for $6000 \mathrm{yr}$ BP, based partly on BIOME 6000 data, in an experiment to assess the consequences of land-surface changes in northern Africa for the strength and seasonal phasing of the African monsoon. Crowley \& Baum (1997) attempted a global prescription of LGM vegetation and showed the potential for strong vegetation feedbacks at LGM; however, this global vegetation reconstruction, based on data compiled during the 1980 s by the COHMAP project (Wright et al., 1993), differs in many substantial ways (for example, the extent of steppe and desert in China) from the picture that we are now able to show for the LGM. The matter of biogeophysical feedbacks at LGM therefore requires re-examination.

We envisage the possibility of using the BIOME 6000 data first to generate altered surface boundary conditions for an atmospheric or coupled atmosphere-ocean model, and then (with appropriate diagnostic procedures) as a benchmark to evaluate whether the model with altered land-surface conditions is more nearly able to reproduce the distribution of biomes for the period in question. There is no circularity here. One rather asks whether the modelled climate system is capable of sustaining the changes that were prescribed, or whether additional processes must be invoked to account for the climate and vegetational changes that took place. Although attention has been focused mainly on certain regions and phenomena where there is a strong prima facie case for biogeophysical feedbacks, we suspect that there is considerable scope for further and more subtle changes in climatic seasonality and circulation patterns mediated by vegetation shifts at a global scale.

\section{ACKNOWLEDGMENTS}

This paper is a contribution to BIOME 6000 (http:// www.bgc-jena.mpg.de/bgc_prentice/), a project sponsored by IGBP through its programme elements GAIM, the IGBP Data and Information System (IGBP-DIS), Global Change and Terrestrial Ecosystems (GCTE) and PAst Global changES (PAGES). The work forms part of the core research of GCTE and GAIM. It was supported in part by the US-EPA grant to 
GAIM (under a subcontract with the University of New Hampshire), in part by the NSF grant to the project Testing Earth system Models with Palaeoenvironmental Observations (TEMPO), and in part by the European Union Environment Programme contract for the Palaeoclimate Modelling Intercomparison Project (PMIP). It was facilitated by the availability of primary pollen data for Europe in the European Pollen Data Base (EPD), for Africa in the African Pollen Data Base (APD), for North America in the North American Pollen Data Base (NAPD), and for the Arctic in the Palaeoecology of Arctic Lakes and Estuaries (PALE) Data Base. EPD and APD have been supported by the European Union, NAPD by the Illinois State Museum and NSF, and PALE by NSF. The graphics and much of the analysis were facilitated by software (BIOMAP and BIOMISE) developed by Ben Smith at Lund University. We thank Gerhard Bönisch for data management, Silvana Schott for technical editing and graphics, and Kerstin Sickel for computing support at MPI-BGC. Nathalie de Noblet provided helpful comments on a draft manuscript.

\section{REFERENCES}

Anonymous (1994) IGBP Global Modelling and Data Activities 1994-98. Global Change Report, 30, 1-87.

Araus, J. L., Febrero, A., Buxo, R., Camalich, M. D., Martin, D., Molina, F., Rodriguez-Ariza, M. O. \& Romagosa, I. (1997) Changes in carbon isotope discrimination in grain cereals from different regions of the western Mediterranean Basin during the past seven millenia. Palaeoenvironmental evidence of a differential change in aridity during the Late Holocene. Global Change Biology, 3, 107-118.

Bartlein, P. J. \& Prentice, I. C. (1989) Orbital variations, climate and palaeoecology. Trends in Ecology and Evolution, 4, 195-199.

Bennett, K. D. (1997) Evolution and ecology: the pace of life, 259 pp. Cambridge University Press, Cambridge.

Braconnot, P., Joussaume, S., Marti, O. \& de Noblet, N. (1999) Synergistic feedbacks from ocean and vegetation on the African monsoon response to mid-Holocene insolation. Geophysical Research Letters, 26, 2481-2484.

Broccoli, A. J. \& Marciniak, E. P. (1996) Comparing simulated glacial climate and paleodata: a reexamination. Paleoceanography, 11, 3-14.

Broström, A., Coe, M., Harrison, S. P., Kutzbach, J. E., Foley, J., Prentice, I. C. \& Behling, P. (1997) Land surface feedbacks and paleomonsoons in northern Africa. Geophysical Research Letters, 25, 3615-3618.

Bruneau de Mire, P. \& Quézel, P. (1959) Sur la présence de la Bruyère en arbre sur les sommets de l'Emi Koussi (Massif du Tibesti). Comptes rendues, Sommaire Séances Société Biogéographie, 34, 66-70.

Cheddadi, R., Yu, G., Guiot, J., Harrison, S. P. \& Prentice, I. C. (1997) The climate of Europe 6000 years ago. Climate Dynamics, $13,1-9$.

Ciret, C. \& Henderson-Sellers, A. (1997) Sensitivity of global vegetation models to present-day climates simulated by global climate models. Global Biogeochemical Cycles, 11, 415-434.

Ciret, C. \& Henderson-Sellers, A. (1998) Sensitivity of ecosystem models to the spatial resolution of the NCAR Community Climate Model CCM2. Climate Dynamics, 14, 409-430.
Claussen, M. \& Esch, M. (1994) Biomes computed from simulated climatologies. Climate Dynamics, 9, 235-243.

Claussen, M. \& Gayler, V. (1997) The greening of Sahara during the mid-Holocene: results of an interactive atmosphere-biome model. Global Ecology and Biogeography Letters, 6, 369-378.

COHMAP Members (1988) Climatic changes of the last 18,000 years: observations and model simulations. Science, 241, 1043-1052.

Colinvaux, P. (1987) Amazon diversity in light of the paleoecological record. Quaternary Science Reviews, 6, 93-114.

Crowley, T. J. \& Baum, S. K. (1997) Effect of vegetation on an ice-age climate model simulation. Journal of Geophysical Research, 102, 16 463-16 480.

Davis, M. B. (1990) Research questions posed by the paleoecological record of global change. Global changes of the past (ed. by R. S. Bradley), pp. 385-396. UCAR/OIES, Boulder, Colorado.

Edwards, M. E., Anderson, P. M., Brubaker, L. B., Ager, T., Andreev, A. A., Bigelow, N. H., Cwynar, L. C., Eisner, W. R., Harrison, S. P., Hu, F.-S., Jolly, D., Lozhkin, A. V., MacDonald, G. M., Mock, C. J., Ritchie, J. C., Sher, A. V., Spear, R. W., Williams, J. \& Yu, G. (2000) Pollen-based biomes for Beringia 18,000, 6000 and $0{ }^{14} \mathrm{C}$ yr BP. Journal of Biogeography, 27, 521-554

Elenga, H., Peyron, O., Bonnefille, R., Prentice, I. C., Jolly, D., Cheddadi, R., Guiot, J., Andrieu, V., Bottema, S., Buchet, G., de Beaulieu, J. L., Hamilton, A. C., Maley, J., Marchant, R., Perez-Obiol, R., Reille, M., Riollet, G., Scott, L., Straka, H., Taylor, D., Van Campo, E., Vincens, A., Laarif, F. \& Jonson, H. (2000) Pollen-based biome reconstructions for southern Europe and Africa 18,000 yr BP. Journal of Biogeography, 27, 621634.

Elias, S. A., Short, S. K. \& Birks, H. H. (1997) Late Wisconsin environments of the Bering Land Bridge. Palaeogeography, Palaeoclimatology, Palaeoecology, 136, 293-308.

Eltahir, E. A. B. (1996) Role of vegetation in sustaining large-scale atmospheric circulations in the tropics. Journal of Geophysical Research, 101, 4255-4268.

Farrera, I., Harrison, S. P., Prentice, I. C., Ramstein, G., Guiot, J., Bartlein, P. J., Bonnefille, R., Bush, M., von Grafenstein, U., Holmgren, K., Hooghiemstra, H., Hope, G., Jolly, D., Lauritzen, S.-E., Ono, Y., Pinot, S., Stute, M. \& Yu, G. (1999) Tropical climates at the last glacial maximum: a new synthesis of terrestrial palaeoclimatic data. I. Vegetation, lakelevels and geochemistry. Climate Dynamics, 15, 823-856.

Foley, J. A., Kutzbach, J. E., Coe, M. T. \& Levis, S. (1994) Feedbacks between climate and boreal forests during the Holocene epoch. Nature, 371, 52-54.

Foley, J. A., Levis, S., Prentice, I. C., Pollard, D. \& Thompson, S. L. (1998) Coupling dynamic models of climate and vegetation. Global Change Biology, 4, 561-579.

Guiot, J., Cheddadi, R., Prentice, I. C. \& Jolly, D. (1996) A method of biome mapping from pollen data: application to Europe 6000 years ago. Palaeoclimates: Data and Modelling, 1, 311-324.

Harrison, S. P. \& Digerfeldt, G. (1993) European lakes as palaeohydrological and palaeoclimatic indicators. Quaternary Science Reviews, 12, 233-248.

Harrison, S. P., Jolly, D., Laarif, F., Abe-Ouchi, A., Dong, B., Herterich, K., Hewitt, C., Joussaume, S., Kutzbach, J. E., Mitchell, J., de Noblet, N. \& Valdes, P. (1998) Intercomparison of simulated global vegetation distribution in response to 6 kyr B.P. orbital forcing. Journal of Climate, 11, 2721-2742. 
Harrison, S. P., Kutzbach, J. E., Prentice, I. C., Behling, P. \& Sykes, M. T. (1995) The reponse of northern hemisphere extratropical climate and vegetation to orbitally-induced changes in insolation during the last interglacial: results of atmospheric general circulation model and biome simulations. Quaternary Research, 43, 174-184.

Harrison, S. P., Prentice, I. C. \& Bartlein, P. J. (1992) Influence of insolation and glaciation on atmospheric circulation in the North Atlantic sector: implications of general circulation model experiments for the Late Quaternary climatology of Europe. Quaternary Science Reviews, 11, 283-300.

Hewitt, C. D. \& Mitchell, J. F. B. (1996) GCM simulations of the climate of $6 \mathrm{kyr}$ BP: mean changes and interdecadal variability. Journal of Climate, 9, 3505-3529.

Hewitt, C. D. \& Mitchell, J. F. B. (1998) A fully coupled GCM simulation of the climate of the mid-Holocene. Geophysical Research Letters, 25, 361-364.

Hoelzmann, P., Jolly, D., Harrison, S. P., Laarif, F., Bonnefille, R. \& Pachur, H.-J. (1998) Mid-Holocene land-surface conditions in northern Africa and the Arabian peninsula: a data set for AGCM simulations. Global Biogeochemical Cycles, 12, 35-52.

Huntley, B. \& Prentice, I. C. (1993) Holocene vegetation and climates of Europe. Global climates since the last glacial maximum (ed. by H. E. Wright Jr, J. E. Kutzbach, T. Webb III, W. F. Ruddiman, F. A. Street-Perrott and P. J. Bartlein), pp. 136-168. University of Minnesota, Minneapolis.

Huntley, B. \& Webb, T., III (1989) Migration: species' reponse to climatic variations caused by changes in the Earth's orbit. Journal of Biogeography, 16, 5-19.

Hyvärinen, H. (1976) Flandrian pollen deposition rates and tree-line history in northern Fennoscandia. Boreas, 5, 163-175.

Jolly, D., Harrison, S. P., Damnati, B. \& Bonnefille, R. (1998b) Simulated climate and biomes of Africa during the Late Quaternary: comparison with pollen and lake status data. Late Quaternary climates: data syntheses and model experiments (ed. by T. Webb III). Quaternary Science Reviews, 17, 629-657.

Jolly, D. \& Haxeltine, A. (1997) Effect of low glacial atmospheric $\mathrm{CO}_{2}$ on tropical African montane vegetation. Science, 276, 786-787.

Jolly, D., Prentice, I. C., Bonnefille, R., Ballouche, A., Bengo, M., Brenac, P., Buchet, G., Burney, D., Cazet, J.-P., Cheddadi, R., Edorh, T., Elenga, H., Elmoutaki, S., Guiot, J., Laarif, F., Lamb, H., Lézine, A.-M., Maley, J., Mbenza, M., Peyron, O., Reille, M., Reynaud-Farrera, I., Riollet, G., Ritchie, J. C., Roche, E., Scott, L., Ssemmanda, I., Straka, H., Umer, M., Van Campo, E., Vilimumbalo, S., Vincens, A. \& Waller, M. (1998a) Biome reconstruction from pollen and plant macrofossil data for Africa and the Arabian peninsula at 0 and $6 \mathrm{ka}$. Journal of Biogeography, 25, 1007-1028.

Joussaume, S. \& Taylor, K. E. (1995) Status of the Paleoclimate Modeling Intercomparison Project (PMIP). WCRP Report 92. Proceedings of the First International AMIP Scientific Conference (Monterey, California, USA, 15-19 May, 1995), 425-430.

Joussaume, S., Taylor, K. E., Braconnot, P., Mitchell, J. F. B., Kutzbach, J. E., Harrison, S. P., Prentice, I. C., Broccoli, A. J., Abe-Ouchi, A., Bartlein, P. J., Bonfils, C., Dong, B., Guiot, J., Herterich, K., Hewitt, C. D., Jolly, D., Kim, J. W., Kislov, A., Kitoh, A., Loutre, M. F., Masson, V., McAvaney, B., McFarlane, N., de Noblet, N., Peltier, W. R., Peterschmitt, J. Y., Pollard, D., Rind, D., Royer, J. F., Schlesinger, M. E., Syktus, J., Thompson, S., Valdes, P., Vettoretti, G., Webb, R. S. \& Wyputta, U. (1999)
Monsoon changes for 6000 years ago: results of 18 simulations from the Paleoclimate Modeling Intercomparison Project (PMIP). Geophysical Research Letters, 26, 859-862.

Kallel, N., Paterne, M., Labeyrie, L., Duplessy, J. C. \& Arnold, M. (1997) Temperature and salinity records of the Tyrrhenian Sea during the last 18,000 years. Palaeogeography, Palaeoclimatology, Palaeocology, 135, 97-108.

Kattenberg, A., Giorgi, F., Grassl, H., Meehl, G. A., Mitchell, J. F. B., Stouffer, R. J., Tokioka, T., Weaver, A. J. \& Wigley, T. M. L. (1996) Climate model projections of future climate. Climate change 1995: the science of climate change (ed. by J. T. Houghton, L. G. Meira Filho, B. A. Callander, N. Harris, A. Kattenberg and K. Maskell), pp. 285-357. Cambridge University Press, Cambridge.

Kutzbach, J. E., Bonan, G., Foley, J. \& Harrison, S. P. (1996) Vegetation/soil feedbacks and African monsoon response to orbital forcing in the Holocene. Nature, 384, 623-626.

Kutzbach, J. E., Gallimore, R., Harrison, S. P., Behling, P., Selin, R. \& Laarif, F. (1998) Climate simulations for the past 21,000 years. Quaternary Science Reviews, 17, 473-506.

Kutzbach, J. E. \& Guetter, P. J. (1986) The influence of changing orbital parameters and surface boundary conditions on the simulated climate of the past 18,000 years. Journal of Atmospheric Sciences, 43, 1726-1759.

Kutzbach, J. E. \& Liu, Z. (1997) Response of the African monsoon to orbital forcing and ocean feedbacks in the Middle Holocene. Science, 278, 440-443.

Kutzbach, J. E. \& Street-Perrott, F. A. (1985) Milankovitch forcing of fluctuations in the level of tropical lakes from 18 to 0 kyr BP. Nature, 317, 130-134.

MacDonald, G. M. (1995) Vegetation of the continental Northwest Territories at $6 \mathrm{ka} \mathrm{BP}$. Géographie physique et Quaternaire, 49, 37-43.

Masson, V., Joussaume, S., Pinot, S. \& Ramstein, G. (1998) Impact of parameterizations on simulated winter mid-Holocene and Last Glacial Maximum climatic changes in the northern hemisphere. Journal of Geophysical Research-Atmospheres, 103, 8935-8946.

Melillo, J., Prentice, I. C., Schulze, E.-D., Farquhar, G. \& Sala, O. (1996) Terrestrial biotic responses to environmental change and feedbacks to climate. Climate change 1995: the science of climate change (ed. by J. T. Houghton, L. G. Meira Filho, B. A. Callander, N. Harris, A. Kattenberg and K. Maskell), pp. 445-482. Cambridge University Press, Cambridge.

Mommersteeg, H. J. P. M., Loutre, M. F., Young, R., Wijmstra, T. A. \& Hooghiemstra, H. (1995) Orbital forced frequencies in the 975,000 year pollen record from Tenagi Philippon (Greece). Climate Dynamics, 11, 4-24.

de Noblet, N., Braconnot, P., Joussaume, S. \& Masson, V. (1997) Sensitivity of simulated Asian and African summer monsoons to orbitally induced variations in insolation 126 , 115 and 6 k BP. Climate Dynamics, 12, 589-603.

de Noblet, N., Prentice, I. C., Joussaume, S., Texier, D., Botta, A. \& Haxeltine, A. (1996) Possible role of atmosphere-biosphere interactions in triggering the last glaciation. Geophysical Research Letters, 23, 3191-3194.

Pinot, S., Ramstein, G., Guiot, J., Harrison, S. P., Joussaume, S., Prentice, I. C. \& PMIP Participating Groups (1999) Tropical palaeoclimates at the last glacial maximum: comparison of Palaeoclimate Modelling Intercomparison Project (PMIP) simulations and palaeodata. Climate Dynamics, 15, 857-874. 
Prentice, I. C. (1988) Records of vegetation in time and space: the principles of pollen analysis. Vegetation history (ed. by B. Huntley and T. Webb III), pp. 17-42. Kluwer, Dordrecht.

Prentice, I. C. (1992) Climate change and long-term vegetation dynamics. Plant succession: theory and prediction (ed. by D. C. Glenn-Lewin, R. A. Peet and T. Veblen), pp. 293-339. Chapman \& Hall, London.

Prentice, I. C. (1998) Ecology and the Earth system. Earth system analysis (ed. by H.-J. Schellnhüber and V. Wenzel), pp. 219240. Springer Verlag, Heidelberg.

Prentice, I. C., Bartlein, P. J. \& Webb, T., III (1991) Vegetation and climate changes in eastern North America since the last glacial maximum. Ecology, 72, 2038-2056.

Prentice, I. C., Guiot, J. \& Harrison, S. P. (1992) Mediterranean vegetation, lake levels and palaeoclimate at the last glacial maximum. Nature, 360, 658-660.

Prentice, I. C., Guiot, J., Huntley, B., Jolly, D. \& Cheddadi, R. (1996) Reconstructing biomes from palaeoecological data: a general method and its application to European pollen data at 0 and $6 \mathrm{ka}$. Climate Dynamics, 12, 185-194.

Prentice, I. C., Harrison, S. P., Jolly, D. \& Guiot, J. (1998) The climate and biomes of Europe at $6000 \mathrm{yr}$ BP: comparison of model simulations and pollen-based reconstructions. Quaternary Science Reviews, 17, 659-668.

Prentice, I. C. \& Sarnthein, M. (1993) Self-regulatory processes in the biosphere in the face of climate change. Global changes in the perspective of the past (ed. by J. Eddy and H. Oeschger), pp. 29-38. Wiley, Chichester.

Prentice, I. C., Sykes, M. T., Lautenschlager, M., Harrison, S. P., Denissenko, O. \& Bartlein, P. J. (1993) Modelling global vegetation patterns and terrestrial carbon storage at the last glacial maximum. Global Ecology and Biogeography Letters, 3, 67-76.

Prentice, I. C. \& Webb, T., III (1998) BIOME 6000: reconstructing global mid-Holocene vegetation patterns from palaeoecological records. Journal of Biogeography, 25, 997-1005.

Quézel, P. (1978) Analysis of the flora of Mediterranean and Saharan Africa. Annals of the Missouri Botanic Garden, 65, 479-533.

Quézel, P. \& Barbero, M. (1993) Variations climatiques au Sahara et en Afrique sèche depuis le Pliocène: enseignements de la flore et de la végétation actuelles. Bulletin d'Ecologie, 24, 191-202.

Richard, P. J. H. (1995) Le couvert végétal du Québec-Labrador il y a 6000 ans BP: essai. Géographie physique et Quaternaire, 49, 117-140.

Ritchie, J. C. (1985) Late Quaternary climatic and vegetational change in the lower Mackenzie basin. Ecology, 66, 612-621.

Ritchie, J. C. (1987) The postglacial vegetation of Canada. Cambridge University Press, Cambridge.

Steffen, W. L., Walker, B. H., Ingram, J. S. \& Koch, G. W. (1992) Global Change and Terrestrial Ecosystems: the operational plan. Global Change Report 21.

Street-Perrott, F. A., Huang, Y. S., Perrott, R. A., Eglinton, G., Barker, P., Ben Khelifa, L., Harkness, D. D. \& Olago, D. O. (1997) Impact of lower atmospheric carbon dioxide on tropical mountain ecosystems. Science, 278, 1422-1426.

Street-Perrott, F. A., Mitchell, J. F. B., Marchand, D. S. \& Brunner, J. S. (1990) Milankovitch and albedo forcing of the tropical monsoons: a comparison of geological evidence and numerical simulations for $9000 \mathrm{yr} \mathrm{BP}$. Transactions of the Royal Society of Edinburgh: Earth Sciences, 81, 407-427.

Sun, X. J. \& Chen, Y. S. (1996) Palynological records of the last 11,000 years in China. Quaternary Science Reviews, 10, 537-544.

Takahara, H., Sugita, S., Harrison, S. P., Miyoshi, N., Morita, Y. \& Uchiyama, T. (2000) Pollen-based reconstructions of Japanese biomes at 0,6000 and $18,000{ }^{14} \mathrm{C}$ yr вP. Journal of Biogeography, 27, 665-683.

Tarasov, P. E., Volkova, V. S., Webb, T., III, Guiot, J., Andreev, A. A., Bezusko, L. G., Bezusko, T. V., Bykova, G. V., Dorofeyuk, N. I., Kvavadze, E. V., Osipova, I. M., Panova, N. K. \& Sevastyanov, D. V. (2000) Last glacial maximum biomes reconstructed from pollen and plant macrofossil data from northern Eurasia. Journal of Biogeography, 27, 609-620.

Tarasov, P. E., Webb, T., III, Andreev, A. A., Afanas'eva, N. B., Berezina, N. A., Bezusko, L. G., Blyakhararchuk, T. A., Bolikhovskaya, N. S., Cheddadi, R., Chernavskaya, M. M., Chernova, G. M., Dorofeyuk, N. I., Dirksen, V. G., Elina, G. A., Filimonova, L. V., Glebov, F. Z., Guiot, J., Gunova, V. S., Harrison, S. P., Jolly, D., Khomutova, V. I., Kvavadze, E. V., Osipova, I. M., Panova, N. K., Prentice, I. C., Saarse, L., Sevastyanov, D. V., Volkova, V. S. \& Zernitskaya, V. K. (1998) Present-day and mid-Holocene biomes reconstructed from pollen and plant macrofossil data from the former Soviet Union and Mongolia. Journal of Biogeography, 25, 1029-1053.

TEMPO (Kutzbach, J. E., Bartlein, P. J., Foley, J. A., Harrison, S. P., Hostetler, S. W., Liu, Z., Prentice, I. C., Webb, T., III) (1996) The potential role of vegetation feedback in the climate sensitivity of high-latitude regions: a case study at 6000 years BP. Global Biogeochemical Cycles, 10, 727-736.

Texier, D., de Noblet, N., Harrison, S. P., Haxeltine, A., Jolly, D., Joussaume, S., Laarif, F., Prentice, I. C. \& Tarasov, P. (1997) Quantifying the role of biosphere-atmosphere feedbacks in climate change: coupled model simulations for 6000 yr в.P. and comparison with palaeodata for northern Eurasia and northern Africa. Climate Dynamics, 13, 865-882.

Thompson, R. S. \& Anderson, K. H. (2000) Biomes of western North America at 18,000, 6000 and $0{ }^{14} \mathrm{C}$ yr BP reconstructed from pollen and packrat midden data. Journal of Biogeography, $27,555-584$.

Thompson, R. S., Whitlock, C., Bartlein, P. J., Harrison, S. P. \& Spaulding, W. G. (1993) Climatic changes in the western United States since 18,000 yr BP. Global climates since the last glacial maximum (ed. by H. E. Wright Jr, J. E. Kutzbach, T. Webb III, W. F. Ruddiman, F. A. Street-Perrott and P. J. Bartlein), pp. 468-513. University of Minnesota Press, Minneapolis.

Webb, T., III, Bartlein, P. J., Harrison, S. P. \& Anderson, K. H. (1993) Vegetation, lake-levels, and climate in eastern North America since $12,000 \mathrm{yr}$ BP. Global climates since the last glacial maximum (ed. by H. E. Wright Jr, J. E. Kutzbach, T. Webb III, W. F. Ruddiman, F. A. Street-Perrott and P. J. Bartlein), pp. 415-467. University of Minnesota Press, Minneapolis.

Wickens, G. E. (1984) Flora. Sahara Desert (ed. by J. L. CloudsleyThompson), pp. 67-75. IUCN/Pergamon Press, Oxford.

Williams, J. W., Webb, T., III, Richard, P. J. H. \& Newby, P. (2000) Late Quaternary biomes of Canada and the eastern United States. Journal of Biogeography, 27, 585-607.

Wright, H. E., Jr, Kutzbach, J. E., Webb, T., III, Ruddiman, W. F., Street-Perrott, F. A. \& Bartlein, P. J. (1993) Global climates 
since the last glacial maximum. University of Minnesota, Minneapolis.

Yu, G., Chen, X., Ni, J., Cheddadi, R., Guiot, J., Han, H., Harrison, S. P., Huang, C., Ke, M., Kong, Z., Li, S., Li, W., Liew, P., Liu, G., Liu, J., Liu, Q., Liu, K.-B., Prentice, I. C., Qui, W., Ren, G., Song, C., Sugita, S., Sun, X., Tang, L., Van Campo, E., Xia, Y., Xu, Q., Yan, S., Yang, X., Zhao, J. \& Zheng, Z. (2000) Palaeovegetation of China: a pollen data-based synthesis for the mid-Holocene and last glacial maximum. Journal of Biogeography, 27, 635-664.

Yu, G. \& Harrison, S. P. (1996) An evaluation of the simulated water balance of Eurasia and northern Africa at $6000 \mathrm{yr}$ BP using lake status data. Climate Dynamics, 12, 723-735.

Yu, G., Prentice, I. C., Harrison, S. P. \& Sun, X. (1998) Pollen-based biome reconstructions for China at $0 \mathrm{ka}$ and $6 \mathrm{ka}$. Journal of Biogeography, 25, 1055-1069.

\section{BIOSKETCHES}

Colin Prentice has led BIOME 6000 since its inception in 1993, when he was Professor of Plant Ecology at Lund University. He has been a director of the Max Planck Institute for Biogeochemistry (MPI-BGC) since 1997. He is a member of GAIM and is on the advisory committee for PMIP.

Dominique Jolly was the GAIM postdoctoral fellow for BIOME 6000 from 1993 to 1998. He is on the steering committee for the African Pollen Data Base (APD).

BIOME 6000 is a community-wide project which was formally inaugurated in 1994 under the auspices of IGBP. 